\title{
Feminism in Shashi Deshpande's That Long Silence and Anita Desai's Cry, the Peacock: A Comparative Study
}

\section{Priti Koolwal}

Asst. Professor (English)

Parikh Manilal Baldevdas Gujarati Commerce College

Indore, M.P, India

preetikoolwal273@gmail.com

Abstract

Feminism is a rapidly developing critical ideology of great promise. In the words of M.K. Bhatnagar, "Feminism in the Indian context is a by product of western liberalism in general and feminist thoughts in particular". With the social and cultural change in post independence India, women find themselves standing at the cross-roads. On one hand it is the consciousness of a changed time and on the other, the socio-cultural modes and values that have given them defined role towards themselves, have led to the fragmentation of the very psyche of these women. Caught between two worlds, they need to define themselves, their place in society and their relationship with surroundings. Anita Desai and Shashi Deshpande have constantly sought to come to grips with these problems of Indian womanhood and vividly and realistically portrayed the 'women question' and 'feministic traits' in their novels. If comparative study is the study of literature across national, political and linguistic boundaries, feminism is the comparative work across boundaries of gender and culture. The main concern of this paper is to present a comparative study of the note of feminism in the best words of both these feministic writers, i.e. Anita Desai's Cry, The Peacock and Shashi Deshpande's That Long Silence. 
Keywords: Feminism, That Long Silence, Cry The Peacock, Marital Relationship, Stream Of Consciousness.

Shashi Deshpande's That Long Silence is an account of the main female protagonist Jaya's own series of memories. It is a story of Jaya who as Sarabjeet Sandhu calls "An intellectual who finds herself out of place in the society meant only for men". Shashi Deshpande delineates 'the delicate swings' of mood, the see-saw movements of joy and despair, the fragment of feelings perceived and suppressed, the life of senses as well as the heart-wringing anguish of the narrator protagonist, Jaya, a housewife, a mother and a failed writer. A sensitive and realistic dramatisation of the married life of Jaya and her husband Mohan, it portrays an inquisitive critical appraisal to which the institution of marriage has been subjected to in recent years. It centres round the inner perception of the protagonist, a woman who in the words of M.K. Bhatnagar, "finds her normal routine so disrupted that for the first time she can look at her life and attempt to decide who she really is, but could she".

Her superstitious belief lead to her disease psyche, mental distress and finally to insanity. She does not have the confidence and modern liberal and individualistic thoughts of the modern women. In contrast, in the novel, Shashi Deshpande has depicted the psychology of such a woman (Jaya), whose desire to live life with modern, liberal and progressive view, is rejected after her marriage by the traditional family of her husband. In a summarized form, Shashi has portrayed a woman author and her struggle for existence. VeenaSheshadri observes : "There must be thousands of self centered women like Jaya, perennially gripping about their fate, but unwilling to do anything that could result in their being tossed out of their in comfortable ruts and into the big, bad world of reality, to fend for themselves".

The question "Who am 1?" haunts her so obsessively that she fails to find herself. She is an utter stranger, a person so alien that even the faintest understanding of the motives of 
her actions seemed impossible. The problem faced by Jaya is existential in nature. Her selfassertion leads to self alienation and loneliness. But it does not lead to insanity as has been depicted in Anita Desai's novel Cry, the Peacock. Delineating a different aspect of feminism, Anita Desai's Cry, The Peacock attempts the delineation of the diseased psyche of a woman on the brink of insanity. "Maya, the protagonist of Cry, The Peacock is a young girl who is obsessed by a childhood prophecy of disaster, a disaster that cannot be averted. The story is also one of marital discord imbued with strong steak of neurotic fantasy on the part of the woman and a corresponding phlegmatic and stolid attitude on the part of her husband"

To Maya, Jaya being influenced by feminism wants to be modern and liberal but she cannot do so which ultimately leads her to tension and suffering. The main reason of Jaya's struggle in That Long Silence is that Jaya wants to develop herself as a woman with liberal thinking. But influenced by the social norms of society, her husband and members of his family rejected her modern view in such a way that she finds herself helpless and becomes silent. She indulges in fight with herself forever. In such a stifling and suffocating domestic ambience and patriarchal set-up, she finds her female identity effaced. Her feminine dilemma is expressed in her female identity effaced. Her feminine dilemma is expressed in her vacillating state of mind: "I could and could not do, all the things that were womanly and unwomanly".

In case of Maya, her 'Struggle for existence' account due to the 'superstition' as well as her emotional and physical dissatisfaction with her husband. Like Maya in Cry, the Peacock, That Long Silence also portrays unhappy and dissatisfied marital relationship between Jaya and her husband Mohan. Due to the differences in their opinion, they fail time and again, to understand each other. It created disharmony and tension between them. This difference of thinking greatly affects their marital life. In this condition they feel that they have lost their mutual love for each other and now their relationship as husband and wife is based on 
compromise them on love or mutual understanding. Her husband could not understand her feelings as a result of which she is torn within.

They were living together for seventeen years, but they never came closer to each other, due to the differences of opinion. It leads to differences and fractions between them, which resulted in dissatisfied married life. This dissatisfied married life is also the main cause of Maya's psychic distress in Cry, The Peacock but there are certain points of differences in the dissatisfied married life of the two protagonist Maya and Jaya. Maya in Anita Desai's Cry, The Peacock is childless. She is denied the warmth and nurturance of motherhood while Jaya in Despande's That Long Silence is the mother of two children. Maya's husband Gautama, the brilliant up and coming lawyer has neither the time nor the capability of showing tenderness towards her. His failure in the traditional role of husband, as a protector acts as a potent catalyst for her collapse. He is pragmatic, unimaginative and deeply engrossed in his work. Hints are thrown about his lack of sexual interest in his wife; in his tender moments which are rare he looks down upon her as tiresome pretty but wayward infant, the spoiled daughter of a rich father. ShantaKrishnaswamy remarks : "He is in a way jealous of her father and this respect and friendship for the older man get steadily eroded, causing one more area of searing pain and bewilderment to Maya."

Jaya is interested in writing, but her husband wants that she should give up writing so as to take full care of their two children and Jaya obeys her husband and sacrifice her greatest desire of writing. This difference of thoughts and views builds a sort of wall in between them and also in their marital life and their marital life grows gloomy and shaky.

Jaya in That Long Silence also makes a flight to childhood but it does not lead her to neurosis or insanity like Maya, but her childhood memories provide a sense of strength to her, when she is in distress. Recalling the ions of her spilt self entangled in her memory, she creates a world of harmony, a world of fantasy, understanding, authentic self hood and a 
composite self. She steps out the narrative actions as a witness as it were, a critic to perceive the tenor of the story filtered through a female consciousness. "Sensual memories are the coldest. They stir up nothing in you. These emotions and responses seemed to belong to two other people, not to the two of us lying here together. Whatever my feeling had been than I had never spoken of them to him".

Deshpande presents her not a woman who has desire to revolt but the one who ultimately reconciles to her hopeless lot. Mohan wonders as to how could women be so rebellious and esoteric, so angry and recalcitrant. Too him, it is unwomanly to be angry for it is against the ideals of feminism.

"A woman can never be angry; and she can only be neurotic, hysterical, frustrated. There is no room for despair either". Marriage subjugates and enslaves women. Women pay for their happiness at the cost of their freedom. The role of wife restricts rather circumscribes woman's self development. Virtually all women engage in the feminine role playing. It is against this encoded and pre-ordained role of women that Jaya and Maya revolts. Theirs is a life of instincts and urges. Jaya unlike other married women slavishly tagged to tradition, she has her own way. Through close-ups and flash-backs, Deshpande has laid bare the psyche of Jaya which is reluctantly responsive and passively secluded. Hence through Jaya's stream of thoughts we find references to many men and women. Jaya owns all disowns none. A veritable symbol of the Universal Mother.

Self-hate is the logical outcome of a conflict between Maya's pride system and her real self. It is a war between the healthy and neurotic forces; i.e. between constructive and destructive elements. The stream of consciousness technique is used by Anita Desai but it becomes abnormal consciousness. The stream of consciousness technique which is an important feature of feminism has been used by both Anita Desai and Deshpande in a different way but both of them present varying feminine traits in the delineation of their 
female protagonist Jaya and Maya. Modern Indian writers like Deshpande and Desai tend to depict the oppression of women with great self consciousness, a deeper sense of involvement and often with a sense of outrage. They present their suffering with much greater realism. In Maya, this consciousness leads to neurotic struggle but in Jaya this consciousness of self identity and reliving the past gives her guidance for her future and she becomes a passive and silent partner of Mohan, coming to the conclusion that life has always to be made possible. Both Anita Desai and Shashi Deshpande present the dilemma of modern Indian women. They write because it is within them. It's their point of view, a world from within the women and this is their remarkable contribution to Indian writing. To conclude with ShantaKrishnaswami, "Given her complimentary role in fiction as well as in society, these novels serve as indicators of the current potential of fictional creativity in India. The Indian woman has lifted up the romantic poliyanna patchwork of a purdah to take a hard look at society's injustice towards her... she has to serve the new dawn through her own eyes". 


\section{References}

M.K. Bhatnagar, Feminist English Literature New Delhi Atlantic Publishers and Distributors, 2003 P.1.

Sarabjeet Sandhu. The Image of Women in That Long Silence ed. R.K. Dhawan, Indian Women Novelists Vol-5, New Delhi Prestige Books, 1991, p-138.

M.K. Bhatnagar, Feminist English Literature New Delhi : Atlantic Publishers and Distributors, 2003 P.64.

Veena Sheshadri, That long Silence, New Delhi Penguin Books, 1988, p.83.

Ibid p.11.

Shanta Krishnaswami The Woman in Indian Fiction in English, New Delhi : Ashish Publishing House, 1984, p-246.

That Long Silence, Ibid p-65.

Ibid p- 147-148.

Shanta Krishnaswami The Woman in Indian Fiction in English, New Delhi, Ashish Publishing House, 1984, P-27. 